\title{
Adverse gestational events associated with prenatal, perinatal and postnatal variables in the Neonatal ICU
}

\author{
Eventos gestacionais adversos associados a variáveis pré-natais, perinatais e pós-natais \\ em UTIN
}
Eventos gestacionales adversos asociados con variables prenatales, perinatales y postnatales en la UCI Neonatal

Emerson Souza da Rocha ${ }^{1}$, Natália Silva da Costa ${ }^{1}$, Lucio Flavio Garcia Rodrigues ${ }^{1}$, Luciana de Fátima da Costa Moraes ${ }^{1}$, Fabiana de Campos Gomes², João Simão de Melo Neto'.

\begin{abstract}
Objective: To analyze whether maternal, obstetric, anthropometric and postnatal variables of neonates admitted to the neonatal intensive care unit (NICU) are different in pregnant women who had adverse gestational events (AGE). In addition, it seeks to analyze whether AGE are predictors of mortality. Methods: Observational, retrospective and quantitative study, with a descriptive and inferential approach based on the medical records of patients seen at the tertiary reference hospital in health located in a municipality in Pará, during 2017. Data were collected to verify the relationship between present and absent AGE. Results: AGE (+) were associated with alcoholism, loss of amniotic fluid, premature labor, breench presentation, increased capillary glycemia and pneumonia. AGE (-) were associated with absent prenatal care, intact amniotic membrane, amniotic fluid with thick meconium and fetal trauma at birth. The other data were not significant. Conclusion: Maternal, obstetric, anthropometric and postnatal variables in neonates admitted to the nicu are associated with $A G E{ }_{(+)}$. The events analyzed did not increase the chances of death.
\end{abstract}

Keywords: Intensive care units, Maternal and child health, Pregnancy.

\section{RESUMO}

Objetivo: Analisar se as variáveis maternas, obstétricas, antropométricas e pós-natais dos neonatos admitidos na unidade de terapia intensiva neonatal (UTIN) são diferentes nas gestantes que apresentaram eventos gestacionais adversos (EGA). Além disso, busca-se analisar se a EGA é preditora de mortalidade. Métodos: Estudo observacional, retrospectivo e quantitativo, com abordagem descritiva e inferencial com base nos prontuários de pacientes atendidos no hospital terciário de referência em saúde localizado em um município do Pará, durante o ano de 2017. Os dados foram coletados para verificar a relação entre eventos gestacionais adversos presente e a ausência. Resultados: EGA (+) esteve associada ao alcoolismo, perda de líquido amniótico, trabalho de parto prematuro, apresentação pélvica, aumento da glicemia capilar e pneumonia. EGA (-) esteve associada ao pré-natal ausente, membrana amniótica intacta, líquido amniótico com mecônio espesso e trauma fetal ao nascimento. Os outros dados não foram significativos. Conclusão: Variáveis maternas, obstétricas, antropométricas e pós-natais em neonatos admitidos no nicu estão associadas à EGA (+). Os eventos analisados não aumentaram as chances de morte.

Palavras-chave: Unidades de terapia intensiva, Saúde materno-infantil, Gravidez.

\section{RESUMEN}

Objetivo: Analizar si las variables maternas, obstétricas, antropométricas y postnatales de los recién nacidos ingresados en la unidad de cuidados intensivos neonatales (UCIN) son diferentes en mujeres embarazadas que tuvieron eventos adversos del embarazo (EAE). Además, busca analizar si EAE es un predictor de mortalidad. Métodos: Estudio observacional, retrospectivo y cuantitativo, con enfoque descriptivo e inferencial

${ }^{1}$ Federal University of Pará (UFPA), Belém - PA. *E-mail: jsmeloneto@gmail.com

${ }^{2}$ School of Medicine of São José do Rio Preto (FAMERP), São José do Rio Preto - SP.

SUBMITTED IN: 5/2020

ACCEPTED IN: $6 / 2020$

PUBLISHED IN: 9/2020

REAS/EJCH | Vol.12(9) | e4043 | DOI: https://doi.org/10.25248/reas.e4043.2020 Página 1 de 10 
basado en las historias clínicas de pacientes atendidos en el hospital terciario de referencia en salud ubicado en un municipio de Pará, durante 2017. Se recopilaron datos para verificar la relación entre eventos adversos del embarazo presente y ausente. Resultados: La EAE (+) se asoció con alcoholismo, pérdida de líquido amniótico, parto prematuro, presentación de presentación pélvica, aumento de la glucemia capilar y neumonía. La EAE (-) se asoció con ausencia de atención prenatal, membrana amniótica intacta, líquido amniótico con meconio espeso y trauma fetal al nacer. Los otros datos no fueron significativos. Conclusión: Las variables maternas, obstétricas, antropométricas y postnatales en los recién nacidos ingresados en el nicu están asociadas con la EAE (+). Los eventos analizados no aumentaron las posibilidades de muerte.

Palabras clave: Unidades de cuidados intensivos, Salud materno-infantil, Embarazo.

\section{INTRODUCTION}

Promoting quality care to maternal health has become a priority in the decisions of the World Health Organization, care for women has become increasingly humanized, with specific assistance being made available to pregnant women and newborns during prenatal, delivery and postpartum, making women a protagonist about their rights to actively decide aspects such as, for example, the type of delivery that favors their expectations and according to their health can be contemplated during the pregnancy planning and process, the which in fact reflects the $38 \%$ drop in the last 20 years related to deaths from gestational complications, which may also be related to the increase in the number of qualified health professionals, which in 1990 were only $58 \%$ and in 2019 increased to $81 \%$ (WHO, 2020).

During the gestational period, many Adverse Gestational Events (AGE) may affect a more specific portion of pregnant women, causing complications for both mother and baby, and may increase morbidity rate and mortality during pregnancy or childbirth classifying these women as high-risk pregnancies (WHO, $2015 \mathrm{e}$ PATRICIA L, 2017). High-risk pregnancy is characterized as the occurrence of any clinical or sociobiological condition that harms the health of the mother or fetus (MS, 2012).

It is observed that health problems during pregnancy have increased worldwide, and the evolution in the diagnosis of these complications Adverse Gestational Events (AGE) is the main factor that impacts this increase (NARAYAN B E NELSON P, 2017). In addition, many risk markers contribute to various complications reaching mothers, and consequently newborns. These indicators may be present even before the beginning of pregnancy, as well as may be inherent to it, being them: maternal, obstetric, demographic factors, environmental conditions, lifestyle, previous reproductive history, and associated clinical comorbidities (MS, 2012).

The gestational condition of the mother defines the clinical evolution and postnatal variables of the ZIneonate, and maternal psychological factors and mother-infant interactions are crucial factors for this prognosis (KABONI W,et al., 2017; JANINA E, et al 2019). Thus, some variable and socioeconomic sociodemographic scans may be positive for gestational conditions, as well as may also be related to greater maternal psychological distress or a less positive mother-infant interaction, which may even cause changes in anthropometric characteristics and postnatal variables of neonates, besides being able to permanently compromise structures and the optimal functioning of neonatal organs and systems (GOUTAUDIER N, et al., 2011; ULRICH F e PETERMANN F, 2016).

Thus, maternal clinical indicators have serious implications for the quality of mother-baby relationships, since the non-ideal maternal condition can influence the decrease in care in relation to the child's demands and needs, influencing cognitive, physical, motor and social development. (BELTRAMI L, et al., 2013; GALVÃO A, et al., 2013)

About $99 \%$ of all maternal deaths occur in developing countries. In Brazil, about 830 women die every day due to pregnancy-related reasons and many of these cases are due to preventable causes (WHO, 2019). Due the occurrence of maternal mortality, the follow-up of these women is extremely important. Prenatal care cannot predict all possible complications that this mother may develop, however, it helps to reduce risk factors that may favor a worse maternal prognosis, leading to other levels of attention if necessary (WILLIAM F, 2015). 
It is necessary to emphasize that EAG are a public health problem, generating high costs and concerns in hospitals with the expenses and investments in technologies for early diagnosis (LIMA S, et al., 2012). In addition, as mothers with complications are responsible for $56 \%$ of hospital expenses in referral hospitals, in addition to having a significantly higher number of readmissions during pregnancy (CIARAN S, et al 2019; SHIBANI P, et al., 2018).

The Neonatal Intensive Care Unit (NICU) is an appropriate place, directed to the care of at-risk newborns with complications and/or abnormalities that may generate risk of death. Premature newborns (gestational age less than 30 weeks; less than $1 \mathrm{~kg}$ ) and newborns who need or have already undergone invasive or highly complex procedures are also directed to NICU care. The immediate identification of all these conditions are essential for the maintenance and recovery of neonatal health (FARIA T e AMADA I, 2018).

It is important to emphasize the influence of epidemiological surveys in helping health teams to have information that improved clinical practice, in addition to helping to know the sociodemographic characteristics and the prevalence of the main diseases and EAG that most affect this population, directing as interventions for mothers at higher risk.

Therefore, the aim of this study was to analyze whether maternal and obstetric factors, anthropometric data and postnatal variables of neonates admitted to the intensive care unit are different in pregnant women who presented EAG. In addition, it seeks to analyze whether adverse gestational events are predictors of neonatal mortality.

\section{METHODS}

\section{Ethical aspects}

The research was conducted after approval by the Research Ethics Committee, n. 2,442,015. The design was performed in accordance with the ethical principles provided for in Resolution 466/12 of the National Health Council of Brazil and was conducted in accordance with the Declaration of Helsinki.

\section{Study design}

Observational, retrospective and quantitative study with descriptive and inferential approach.

\section{Characterization of the place and period of study}

The study was developed with data from medical records of patients treated at the tertiary reference hospital in health located in a municipality in Pará, during the year 2017.

\section{Participants}

Mothers of newborns of both sexes, born at the tertiary reference hospital in health located in a municipality in Pará, referred to the Neonatal Intensive Care Unit (NICU).

\section{Sampling}

The sampling was probability with a simple random sample.

\section{Sample}

The initial sample consisted of 651 medical records. After the inclusion and exclusion criteria, 609 records were selected, divided between groups: present Adverse Gestational Events (AGE $\left(_{+}\right) n=470$ ) or absent Adverse Gestational Events (AGE $(-) \mathrm{n}=139)$ AGE.

The minimum number of 398 medical records (present [ $n=306]$ or absent [ $n=92]$ AGE) to be analyzed was obtained after sample size calculation, based on pilot data from this study. This analysis was performed using the Odds ratio (OR: 2.352), provided with the analysis of the association between adverse gestational events with premature birth. For this calculation, it was established: two-tail, proportion p2: 0.14 , relation of allocation N2/N1: 0.30 , erro $\alpha=0.05$ and $\beta=0.2$. 


\section{Exclusion criteria}

Medical records with incomplete medical data that prevented the collection of information were excluded.

\section{Inclusion criteria}

This study included medical records of pregnant women with or without Adverse Gestational Events (AGE) who had their newborns directed to the Neonatal Intensive Care Unit (NICU). The medical records included were distributed in the groups present or absent AGE.

\section{Data collection}

For data collection, we used a form elaborated by the authors containing variables: Maternal factors, obstetric factors, anthropometric data of the newborn and its postnatal variables. After completing the forms with the information relevant to the research, the data were tabulated and compared to verify the relationship between the adverse gestational events and the different factors.

\section{Primary outcomes}

AGE analyzed were urinary tract infections (UTIs), leukorrhea, anemia, chorioamnionitis, hypertensive disorders of pregnancy [HDP], bleeding and diabetes. The maternal factors analyzed were: time of pregnancy, number of deliveries, occurrence of abortion, number of pregnancies, prenatal care regardless of the number of visits, alcoholism, amniotic fluid leakage, premature labor, premature rupture of membrane and sexually transmitted infection (STI's).

The obstetric factors studied were amniotic fluid (clear with or without lumps, thick and thin meconial or bloody), type of delivery (cesarean or vaginal), use of spinal anesthesia, fetal presentation (breench, cephalic or umbilical cord around fetal neck), fetal trauma at birth, single delivery and amniotic membrane condition (intact or rupture). Anthropometric data were height, weight, cephalic perimeter, thoracic perimeter, abdominal perimeter and capillary glycemia.

The clinical variables in the postnatal evaluated were signs of respiratory failure (apnea, cyanosis, nasal flaring, retraction [intercostal, subcostal, supracostal], wailing), resuscitation maneuvers, use of ventilatory support (continuous positive airway pressure [CPAP], invasive mechanical ventilation [IMV] and surfactant) complications (jaundice, atelectasis and pneumonia) and mortality.

\section{Statistical analysis}

After verifying the normality of the data by the Lilliefors test, they were presented as mean and standard deviation (parametric data) or median with interquartiles (first and third) (non-parametric data). To verify intergroup differences, unpaired t tests (parametric data) and Mann-Whitney (nonparametric data) were used. Categorical variables were presented with absolute frequency.

The Chi-square test with Yates correction was used to analyze the association between categorical variables. To quantify the level of association, odds ratios $(\mathrm{OR})$ with a $95 \%$ confidence interval $(95 \% \mathrm{Cl})$ were used.

\section{RESULTS}

Maternal age differed between groups (AGE $(+)$ : 25 [20-31] years; AGE $(-)$ : 23 [19-29] years; Mann-Whitney test $p=0.0344)$. Among the AGE, the most prevalent were anemia $(n=63)$, amniotic fluid leakage $(n=25)$, bleeding $(n=94)$, chorioamnionitis $(n=13)$, diabetes $(n=9)$, HDP $(n=111)$, leukorrhea $(n=217)$, urinary tract infection $(n=252)$. The pregnant women presented to one event $(n=224)$, two $(n=168)$, three $(n=6)$ and four events $(n=12)$. Male neonates were more prevalent in both groups ( $A G E_{(+)}: n=265 ; A G E_{(-)}: n=83$ ).

The maternal and obstetric factors analyzed are presented in Tables 1 and 2, respectively. The maternal factors are presented in Table 1. Among the maternal variables analyzed, alcoholism during pregnancy, loss of amniotic fluid and premature labor were associated with women who had AGE, while absent prenatal care was presented more by women without complications. 
Table 1 - Maternal factors of neonates admitted to the intensive care unit.

\begin{tabular}{|c|c|c|c|c|c|}
\hline Variables & $\begin{array}{l}\text { AGE }_{(+)} \\
n=470\end{array}$ & $\begin{array}{l}\text { AGE }_{(-)} \\
n=139\end{array}$ & OR & $95 \% \mathrm{Cl}$ & $\mathbf{p}$ \\
\hline \multicolumn{6}{|l|}{ Time of pregnancy } \\
\hline$\leq 24$ weeks & 39 & 14 & 0.8079 & $0.4250-1.5357$ & 0.6308 \\
\hline 25-28 weeks & 90 & 23 & 1.1945 & $0.7224-1.9752$ & 0.5693 \\
\hline 29-32 weeks & 198 & 52 & 1.2179 & $0.8552-1.7976$ & 0.3707 \\
\hline 33-36 weeks & 108 & 39 & 0.7650 & 0.4987-1.1735 & 0.2642 \\
\hline $37-40$ weeks & 27 & 9 & 0.8804 & $0.4038-1.9192$ & 0.9077 \\
\hline Uninformed & 8 & 2 & - & - & -- \\
\hline \multicolumn{6}{|l|}{ Number of deliveries } \\
\hline 00 & 165 & 50 & 0.9630 & $0.6488-1.4291$ & 0.9311 \\
\hline 01 & 164 & 42 & 1.2378 & $0.8225-1.8627$ & 0.3565 \\
\hline 02 & 58 & 21 & 0.7910 & $0.4612-1.3567$ & 0.4781 \\
\hline$\geq 03$ & 80 & 21 & 1.1526 & 0.6833-1.9443 & 0.6869 \\
\hline Uninformed & 3 & 5 & - & -- & - \\
\hline \multicolumn{6}{|l|}{ Abortion } \\
\hline 00 & 356 & 115 & 0.6517 & $0.4001-1.0615$ & 0.1066 \\
\hline 01 & 75 & 16 & 1.4597 & $0.8202-2.5977$ & 0.2475 \\
\hline$\geq 02$ & 32 & 3 & 3.3120 & 0.9986-10.985 & 0.0626 \\
\hline Uninformed & 7 & 5 & - & - & - \\
\hline \multicolumn{6}{|l|}{ Number of pregnancies } \\
\hline 00 & 4 & 4 & 0.2897 & $0.0715-1.1737$ & 0.1557 \\
\hline 01 & 181 & 50 & 1.1148 & $0.7525-1.6516$ & 0.6581 \\
\hline 02 & 124 & 38 & 0.9525 & $0.6223-1.4580$ & 0.9087 \\
\hline$\geq 03$ & 158 & 43 & 1.1306 & 0.7523-1.6992 & 0.6255 \\
\hline Uninformed & 3 & 4 & - & - & - \\
\hline Absent prenatal & 39 & 38 & 0.2405 & $0.1464-0.3952$ & $0.0001^{*}$ \\
\hline Alcoholism & 15 & 0 & - & - & $0.0285^{*}$ \\
\hline Amniotic fluid leakage & 25 & 0 & - & - & $0.0024^{*}$ \\
\hline Premature labor & 98 & 14 & 2.3522 & $1.2967-4.2668$ & $0.0058^{*}$ \\
\hline $\begin{array}{c}\text { Premature rupture of } \\
\text { membrane }\end{array}$ & 42 & 9 & 1.4174 & $0.6721-2.9894$ & 0.4556 \\
\hline STI's & 4 & 3 & 0.3891 & $0.0860-1.7599$ & 0.4138 \\
\hline
\end{tabular}

Subtitle: ${ }^{*} \mathrm{p} \leq 0.05$, Chi-square test with Yates correction. OR: Odds ratio; $95 \% \mathrm{Cl}$ : confidence interval; AGE: adverse gestational events; UTI: urinary tract infection; STI's: sexually transmitted infection. Fonte: Rocha ES, et al., 2020. 
Table 2 shows obstetric factors. The variables intact amniotic membrane, amniotic fluid with thick meconium and fetal trauma at birth were more associated with women who had no AGE, while breench presentation was presented by women of the $A G E_{(+)}$. We observed that in the $A G E_{(-)}$group, the increase in the weight of neonates was a determining variable for the presence of fetal trauma at birth (present: $1060 \mathrm{~kg}$ (787.5 - 1548.7); absent: $1732.5 \mathrm{~kg}$ (1340 - 2398.7); Mann-Whitney test $p=0.0001)$ and amniotic fluid with thick meconium (present: $2547.5 \mathrm{~kg}$ (2070 - 2872.5); absent: $1570 \mathrm{~kg}$ (1087.5 - 2128.7); Mann-Whitney test $p=0.0021)$.

Table 2 - Obstetric factors of neonates admitted to the intensive care unit.

\begin{tabular}{|c|c|c|c|c|c|}
\hline Variables & $\begin{array}{l}\operatorname{AGE}_{(+)} \\
n=470\end{array}$ & $\begin{array}{l}\operatorname{AGE}_{(-)} \\
n=139\end{array}$ & OR & $95 \% \mathrm{Cl}$ & $\mathbf{p}$ \\
\hline \multicolumn{6}{|l|}{ Amniotic fluid } \\
\hline Clear with lumps & 133 & 33 & 1.2677 & $0.8171-1.9669$ & 0.3413 \\
\hline $\begin{array}{l}\text { Clear or without } \\
\text { lumps }\end{array}$ & 177 & 45 & 1.2619 & $0.8448-1.2250$ & 0.2997 \\
\hline Thick meconium & 22 & 18 & 0.3301 & $0.1716-0.6352$ & $0.0011^{*}$ \\
\hline Thin meconium & 20 & 3 & 2.0148 & $0.5898-6.8833$ & 0.3756 \\
\hline Bloody & 28 & 3 & 2.8718 & $0.8597-9.5930$ & 0.1163 \\
\hline Uninformed & 90 & 37 & - & - & - \\
\hline \multicolumn{6}{|l|}{ Type of delivery } \\
\hline Caesarean & 264 & 73 & 1.1587 & $0.7928-1.6935$ & 0.5068 \\
\hline Vaginal & 196 & 61 & 0.9147 & $0.6243-1.3401$ & 0.7188 \\
\hline Uninformed & 10 & 5 & - & - & - \\
\hline Spinal anesthesia & 254 & 63 & 1.4186 & $0.9701-2.0745$ & 0.0871 \\
\hline \multicolumn{6}{|l|}{ Fetal presentation } \\
\hline Cephalic & 333 & 108 & 0.6977 & $0.4466-1.0900$ & 0.1392 \\
\hline Breench & 96 & 15 & 2.1219 & $1.1871-3.7930$ & $0.0139^{*}$ \\
\hline $\begin{array}{l}\text { Umbilical cord } \\
\text { around fetal neck }\end{array}$ & 4 & 3 & 0.3891 & $0.0860-1.7599$ & 0.4138 \\
\hline uninformed & 33 & 13 & - & - & - \\
\hline $\begin{array}{l}\text { Fetal trauma at } \\
\text { birth }\end{array}$ & 19 & 46 & 0.0852 & $0.0477-0.1520$ & $0.0001^{*}$ \\
\hline Single delivery & 92 & 157 & 0.7703 & $0.4373-1.3597$ & 0.4419 \\
\hline \multicolumn{6}{|l|}{$\begin{array}{l}\text { Amniotic } \\
\text { membrane }\end{array}$} \\
\hline Intact & 222 & 81 & 0.6410 & $0.4372-0.9398$ & $0.0285^{*}$ \\
\hline Rupture & 131 & 38 & 1.0271 & $0.6721-1.5695$ & 0.9874 \\
\hline Uninformed & 117 & 62 & - & - & - \\
\hline
\end{tabular}

Subtitle: ${ }^{*} p \leq 0.05$, Chi-square test with Yates correction. OR: Odds ratio; $95 \%$ Cl: confidence interval; AGE: adverse gestational events.

Fonte: Rocha ES, et al., 2020.

Table 3 presents anthropometric data of neonates. The variable capillary glycemia was increased in the group of gestational complications present. 
Table 3 - Anthropometric data of neonates admitted to the intensive care unit.

\begin{tabular}{cccc}
\hline Variables & $\begin{array}{c}\mathbf{A G E}_{(+)} \\
\mathbf{n = 4 7 0}\end{array}$ & $\begin{array}{c}\mathbf{A G E}_{(-)} \\
\mathbf{n}=139\end{array}$ & $\mathbf{p}$ \\
\hline $\begin{array}{c}\text { Height }(\mathrm{cm}) \\
\text { Weight }(\mathrm{g})\end{array}$ & $\begin{array}{c}40[36.5-45.5] \\
1465[1070-2176.2]\end{array}$ & $\begin{array}{c}41[37.8-46] \\
1545[1105-2185]\end{array}$ & 0.0649 \\
\hline $\begin{array}{c}\text { Cephalic perimeter } \\
(\mathrm{cm})\end{array}$ & $29[26-32]$ & $29.5[27-33]$ & 0.3786 \\
\hline $\begin{array}{c}\text { Thoracic perimeter } \\
(\mathrm{cm})\end{array}$ & $25[22-28]$ & $25.5[22.5-28]$ & 0.1214 \\
\hline $\begin{array}{c}\text { Abdominal perimeter } \\
(\mathrm{cm})\end{array}$ & $23[20.5-27]$ & $23.5[21-26]$ & 0.4373 \\
\hline Capillary glycemia & $77[57-101]$ & $80[65-109.5]$ & $0.0448^{*}$ \\
\hline
\end{tabular}

Subtitle: ${ }^{*} p \leq 0.05$, Mann-Whitney test. Fonte: Rocha ES, et al., 2020.

Table 4 shows the postnatal data. We observed that pneumonia was less associated with the group with gestational complications.

Table 4 - Postnatal variables of neonates admitted to the intensive care unit.

\begin{tabular}{cccccc}
\hline Variables & $\begin{array}{c}\mathbf{A G E}_{(+)} \\
\mathbf{n = 4 7 0}\end{array}$ & $\begin{array}{c}\mathbf{A G E}_{(-)} \\
\mathbf{n = 1 3 9}\end{array}$ & OR & $\mathbf{9 5 \%} \mathbf{C l}$ & $\mathbf{p}^{*}$ \\
\hline $\begin{array}{c}\text { Signs of respiratory } \\
\text { failure }\end{array}$ & & & & & \\
\hline Apnea & 83 & 35 & 0.6373 & $0.4062-0999$ & 0.0645 \\
Cyanosis & 134 & 40 & 0.9871 & $0.6497-1.4997$ & 0.9635 \\
Nasal flaring & 294 & 74 & 1.4673 & $1.0014-2.1499$ & 0.0609 \\
Wailing & 206 & 55 & 1.1917 & $0.8103-1.7527$ & 0.4270 \\
Retraction & 317 & 86 & 1.2769 & $0.8620-1.8914$ & 0.2633 \\
Resuscitation maneuvers & 293 & 99 & 0.6688 & $0.4430-1.0097$ & 0.0687 \\
Uninformed & 177 & 40 & - & - & - \\
\hline Ventilatory support & & & & & \\
\hline CPAP & 88 & 33 & 0.7400 & $0.4698-1.1655$ & 0.2374 \\
IMV & 134 & 41 & 0.9533 & $0.6289-1.4449$ & 0.9053 \\
Surfactant & 174 & 44 & 1.2692 & $0.8478-1.9000$ & 0.2897 \\
\hline Complications & & & & & \\
\hline Jaundice & 217 & 71 & 0.8215 & $0.5624-1.1998$ & 0.3567 \\
Atelectasis & 11 & 1 & 3.3072 & $0.4232-258439$ & 0.3894 \\
Pneumonia & 14 & 12 & 0.3249 & $0.1466-0.7201$ & $0.0079^{*}$ \\
\hline Mortality & 118 & 41 & 0.8013 & $0.5265-1.2195$ & 0.3548 \\
\hline
\end{tabular}

Subtitle: ${ }^{*} p \leq 0.05$, Chi-square test with Yates correction. OR: Odds ratio; $95 \% \mathrm{Cl}$ : confidence interval; AGE: adverse gestational events; CPAP: continuous positive airway pressure; IMV: invasive mechanical ventilation. Fonte: Rocha ES, et al., 2020.

\section{DISCUSSION}

NICU is the place for clinical care of premature newborns with risk complications. Knowledge of the characteristics involving newborns of pregnant women who presented AGE, contributes to recovery and better prognosis. In this context, this study found that AGE were associated with some maternal, obstetric, anthropometric and postnatal variables in neonates admitted to the NICU.

The most frequent AGE in the study was urinary tract infection. Infections are one of the most prevalent occurrences among pregnant women and may be symptomatic or non-symptomatic (DUARTE G, et al., 2017), according to the results of our study. During the gestational period many physiological changes occur in the urogenital tract of the woman, such as: urethral compression, increased urine output, vesicoureteral reflux, decreased antibacterial activity, among others (DUARTE G, et al., 2017). Moreover, in this period, the therapeutic possibilities against infectious agents and prophylactic possibilities are smaller, taking into account the malignancy of drugs for the fetus (DUARTE G, et al., 2017) thus contributing to the occurrence of infections during the gestational period. 
AGE were associated with alcoholism. During pregnancy, women are guided and motivated by health professionals to make changes in daily living habits. The performance of health education addressing the effects of alcohol use in pregnancy and the specific risks to the fetus and perinatal involving the health of the newborn are practices of these professionals. High alcohol consumption in the second and third trimesters increases prostaglandin secretion, increasing uterine contractions and may induce increased intravascular coagulation, decreasing blood flow in the placenta (IKEHARA S, et al., 2019), which may be associated with preterm delivery and loss of amniotic fluid, as observed in this study. In addition, women are less tolerant of alcohol, making alcohol levels higher and thus more susceptible to the changes it can cause.

In pregnant women, ethanol can cross the placenta by concentration gradient without going through any process of change in its composition, resulting in a fetal level equivalent to the maternal one. In addition, alcohol also has the ability to cross the blood-brain barrier and cause complexes and, in some cases, even irreversible damage to the newborn's health, also causing neurological abnormalities (MESQUITA M, et al., 2010). In addition, alcoholism is related to damage to the newborn in the postnatal period, which may involve growth and weight gain disorders, behavioral dysfunctions, among others (FREIRE K, et al., 2019).

Premature labor, loss of amniotic fluid and Breech presentation were associated with AGE. Every pregnancy is subject to complications and women with AGE are more likely to have a premature delivery (VARELA P, et al., 2017; MEHARI M, et al., 2020) because they present high chances of developing stresses and disorders due to the history of previous diseases, which may result in loss of amniotic fluid.

This fact may be subject to the socioeconomic scenario to which this pregnant woman belongs, for this same factor, added to possible genetic and environmental conditions, studies congruent to our results reveal an association between gestational complications and the risk of pelvic fetal presentation. Regional socioeconomic status, genetic and environmental conditions are factors that influence these conditions and may result in increased risk of Breech presentation (NOLI S, et al., 2019; FREITAS P, et al., 2010).

AGE were associated with higher capillary glycemia. During pregnancy, fetal glucose is influenced by maternal circulation through transplacental transfusion, thus seeking to establish the normality of this parameter in $2 / 3$ of maternal glucose. Neonates with respiratory disorders are more likely to develop hyperglycemia in the postnatal period, and ICU are sites with neonates largely premature and affected by respiratory problems (FALCÃO M e RAMOS J, 1998) thus justifying the change in this population.

AGE were associated with pneumonia. Respiratory diseases are one of the main reasons for admission of newborns to the NICU, including pneumonia (BASEER K, et al., 2020) provided by infections of bacteria, viruses, fungi and parasites. These infections may come from vertical contamination. Generally, it presents early onset that occurs due to pathogens aspirated by the newborn from the intrauterine environment or the birth canal during vaginal delivery, or, late caused by pathogens found in the postnatal environment (KAWAKITA T, et al., 2017).

Among the AGE analyzed, urinary tract infections and gestational diabetes mellitus may be indicative of risk for neonatal respiratory morbidity. Insulin seems to decrease the expression of surfactant protein present in fetal lung tissue, in addition, this factor can also be attributed to prematurity, (KAWAKITA T, et al., 2017) which increases respiratory distress in neonates (LIU J, et al., 2014; BECKLAKE MR e KAUFFMANN F 1999; BAUMERT M, et al., 2012).

Intact amniotic membrane was associated with absent AGE. This anatomical structure contributes to the maintenance of pregnancy (MOORE K.L, 2013). However, we also observed the association with prenatal absentee. The absence of consultations may be related to the adequate development of pregnancy. However, the Northern region of Brazil presents the worst performance associated with geographical difficulties, long distances, barriers in access to diagnostic centers, absence of qualified professionals and the late onset of prenatal care in women (LEAL M, et al., 2020).

In Brazil there are a number of deficiencies in this process, such as number of inadequate consultations, incomplete procedures and others with late onset, behaviors that directly affect perinatal aspects (NUNES J, et al., 2016; SAAVEDRA JS e CESAR JA, 2015). 
Therefore, these factors should be considered in relation to prenatal absentee. Still, in women with absent AGE, the amniotic fluid with thick meconium and fetal trauma at birth have been increased. However, we observed that these associations were due to increased birth weight, as observed by other studies (BURJONRAPPA S, et al., 2010; HAILU LD e KEBEDE DL, 2018).

Knowing the maternal, obstetric, anthropometric and postnatal variables that may be associated with the AGE is essential for the development of public policies. It is possible to observe a large number of uninformed data that impair and greatly limit the analysis carried out in studies using the database. Although there is a reduction in underreporting, there is still a lot to improve of the data.

Thus, in our study, the findings indicated that the variables analyzed are multifactorial related indicating the relevance of this type of study both for the scientific community and for the development of public policies for the Unified Health System (SUS) that favor responses directed to the most present adversities. In addition, to promote a better training of professionals who crave biopsychosocial ideals in both maternal and neonatal treatment.

Health professionals should stimulate through strategies to raise awareness about prenatal care already in the first trimester of pregnancy, aiming to promote the health of pregnant women and newborns. We know that there is a high incidence of neonatal deaths due to preventable causes, so professional follow-up with the mother is extremely important to generate the perception of possible diseases during pregnancy.

\section{CONCLUSION}

In this study, we found that the maternal, obstetric, anthropometric and postnatal variables in neonates admitted to the NICU are associated with AGE. AGE ${ }_{(+)}$were associated with alcoholism, loss of amniotic fluid, premature labor, Breech presentation, increased capillary glycemia and pneumonia. AGE (-) were associated with absent prenatal care, intact amniotic membrane, amniotic fluid with thick meconium and fetal trauma at birth. The events analyzed did not increase the chances of death.

\section{ACKNOWLEDGEMENTS}

We are grateful to the Tertiary Hospital of Reference in Health located in a municipality in Pará, whose main objectives are: Assistance, Teaching and Research, aligned with the profile of assistance in child health, attention to women's health and health of the adult, offering outpatient and inpatient care. The hospital serves $100 \%$ of the Unified Health System (SUS), being registered as a reference in the care of high-risk pregnant women and newborns. We also thank the Laboratory for Clinical and Experimental Research on the Urogenital System (UPCEURG - UFPA).

\section{REFERÊNCIAS}

1. BASEER K, et al. Risk Factors of Respiratory Diseases Among Neonates in Neonatal Intensive Care Unit of Qena University Hospital, Egypt. Ann Glob Health. 2020; 86(1): 22.

2. BELTRAMI, L. Ansiedade materna puerperal e risco para o desenvolvimento infantil. Distúrbio Comum. 2013; 2(23): 229-239.

3. BAUMERT M, et al. Cesarean delivery and respiratory distress in late preterm and term infants. Cent Eur J Med. 2012; 7 (2): 230-234.

4. BECKLAKE MR, KAUFFMANN F. Gender differences in airway behaviour over the human life span. Thorax. 1999; 54(12): 1119-1138.

5. BRASIL. MINISTÉRIO DA SAÚDE (MS). Secretaria de Atenção à Saúde. Departamento de Ações Programáticas Estratégicas. Gestação de alto risco: manual técnico. 5ed. Brasília; 2012:302p.

6. BURJONRAPPA S, et al. The role of amniotic fluid in influencing neonatal birth weight. J Perinatol 2010; 30: 27-29.

7. CIARAN S, et al. Birth Hospitalization Costs and Days of Care for Mothers and Neonates in California 2009-2011. J Pediatr. 2019; 204: 118-125.e14.124

8. DUARTE G, et al. Urinary Infection in Pregnancy: Analysis of Diagnostic Methods and Treatment.Rev. Bras. Ginecol. Obstet. 2002; 24: 471-477

9. FALCÃO M, RAMOS J. Hyperglycemia and glycosuria in preterm infants receiving parenteral glucose: influence of birth weight, gestational age and infusion rate.J. pediatr. 1998; 74(5): 389-396:

10. FARIA T, KAMADA I. Vista de Lesiones de la piel en neonatos en cuidados intensivos neonatales.pdf. Enferm Glob. 2018;17(49): 211-36. 
11. FREIRE K, et al. Factors associated to alcohol and smoking use in pregnancy. Rev. Bras. Ginecol. Obstet. 2009; 31( 7 ): 335-341

12. FREITAS $P$, et al. Perfil das mães de neonatos com controle glicêmico nas primeiras horas de vida. Rev. esc. enferm. 2010; 44( 3 ): 636-641.

13. GAIVA M, et al. Maternal and child risk factors associated with neonatal mortality. Text \& context - nursing. 2016 Dec; vol.25 no.4 Florianópolis.

14. GALVÃO A, et al. Prevalence of postpartum depression and associated factors: integrative review. Re On Facema. 2015; 1(1): 54-58.

15. GOUTAUDIER N, et al. Premature birth: Subjective and psychological experiences in the first weeks following childbirth, a mixed-methods study. Journal of Reproductive and Infant Psychology. 2011; 29:364-373.

16. HAILU LD, KEBEDE DL. Determinants of Low Birth Weight among Deliveries at a Referral Hospital in Northern Ethiopia. Biomed Res Int. 2018; 23: 8169615.

17. IKEHARA S,et al. Japan Environment Children's Study Group. Association between maternal alcohol consumption during pregnancy and risk of preterm delivery: the Japan Environment and Children's Study. BJOG. 2019;126(12): 1448-1454

18. JANINA E, et al. Gestational weight gain, physical activity, sleep problems, substance use, and food intake as proximal risk factors of stress and depressive symptoms during pregnancy. BMC Pregnancy Childbirth. 2019; 19:175.

19. KABONI W, et al. The Role of Sociodemographic Factors in Maternal Psychological Distress and Mother-Preterm Infant Interactions. Res Nurs Health. 2017; 40(6): 528-540.

1. 10. KAWAKITA T, et al. Increased Neonatal Respiratory Morbidity Associated with Gestational and Pregestational Diabetes: A Retrospective Study. Am J Perinatol. 2017; 34(11): 1160-1168.

20. LEAL M, et al. Prenatal care in the Brazilian public health services. Revista de saúde pública. 2020; 54:08.

21. LIMA S, et al. Assessment of hypertensive pregnant women's hospitalization costs at a University Hospital in São Paulo state. RAS. Revista de Administração em Saúde. 2012; 14(57): 167-171.

22. LIU J, et al. High-risk Factors of Respiratory Distress Syndrome in Term Neonates: A Retrospective Case-control Study. Balkan Med J. 2014; 31(1): 64-68.

23. MEHARI M, et al. Advanced maternal age pregnancy and its adverse obstetrical and perinatal outcomes in Ayder comprehensive specialized hospital, Northern Ethiopia, 2017: a comparative cross-sectional study. BMC Pregnancy Childbirth. 2020; 20, 60.

24. MESQUITA M. The effects of alcohol in newborns. Einstein. 2010; 8(3):368-75

25. MINISTÉRIO DA SAÚDE. 2012. In: Gestação de Alto Risco, Manual Técnico. Disponível em: http://bvsms.saude.gov.br/bvs/publicacoes/manual_tecnico_gestacao_alto_risco.pdf. Acesso em: 08 april. 2020

26. MOORE, K. L. Anatomia orientada para a clínica. In Anatomia orientada para a clínica. Rio de Janeiro: Guanabara Koogan, 2013; 1136p.

27. NARAYAN B, NELSON P. Medical problems in pregnancy. Clin Med (Lond). 2017; 17(3): 251-257.

28. NOLI S, et al. Preterm Birth, Low Gestational Age, Low Birth Weight, Parity, and Other Determinants of Breech Presentation: Results from a Large Retrospective Population-Based Study. Biomed Res Int. 2019;2019:9581439.

29. NUNES J, et al. Qualidade da assistência pré-natal no Brasil: revisão de artigos publicados de 2005 a 2015 . Cad. saúde colet. 2016 24( 2 ): 252-261

30. PATRíCIA L, et al. Intercorrências na gravidez em puérperas brasileiras atendidas nos sistemas público e privado de saúde. Rev. Latino-Am. Enfermagem 2017; 25: e 2949

31. SAAVEDRA JS, CESAR JA. Uso de diferentes critérios para avaliar atendimento pré-natal inadequado: um estudo de base populacional no sul do Brasil. Cad Saúde Pública. 2015; 31(5): 1003-1014.

32. SHIBANI P, et al. Short and long-term costs among women experiencing preterm labour or preterm birth: the German experience. BMC Pregnancy Childbirth. 2018; 18: 284.

33. ULRICH F, PETERMANN F. Consequences and possible predictors of health-damaging behaviors and mental health problems in pregnancy - A review. Geburtshilfe Frauenheilkd. 2016; 76(11): 1136-1156.

34. VARELA P, et al. Intercorrências na gravidez em puérperas brasileiras atendidas nos sistemas público e privado de saúde. Rev. Latino-Am. Enfermagem 2017;25:e2949

35. WILLIAM F, et al. At-Risk Pregnancies. Obstet Gynecol Clin North Am. 2015 Jun;42(2): 13-19

36. WORLD HEALTH ORGANIZATION (WHO). 2015. Trends in maternal mortality: 1990 to 2015: estimates by WHO, UNICEF, UNFPA, World Bank Group The United Nations Population Division. Disponível em: https://www.who.int/reproductivehealth/publications/monitoring/maternal-mortality-2015/en/. Acesso em: 9 april. 2020.

37. WORLD HEALTH ORGANIZATION (WHO). 2019. Fact sheet - Maternal mortality. Disponível em: https://www.who.int/news-room/fact-sheets/detail/maternal-mortality. Acesso em: 8 april. 2020.

38. WORLD HEALTH ORGANIZATION (WHO). 2020. Maternal Health.Disponível em: https://www.who.int/healthtopics/maternal-health\#tab=tab_2. Acesso em 8 april. 2020 